\title{
Effect of Instrumentation using Curettes, Piezoelectric Ultrasonic Scaler and Er,Cr:YSGG Laser on the Morphology and Adhesion of Blood Components on Root Surfaces - A SEM Study
}

\author{
Jackeline do Nascimento TSURUMAKI \\ Bráulio Henrique Marques SOUTO \\ Guilherme José Pimentel Lopes de OLIVEIRA \\ José Eduardo Cézar SAMPAIO \\ Elcio MARCANTONIO JÚNIOR \\ Rosemary Adriana Chiérici MARCANTONIO
}

Araraquara Dental School, UNESP - Univ. Estadual Paulista, Araraquara, SP, Brazil

\begin{abstract}
This study used scanning electron microscopy (SEM) to evaluate the morphology and adhesion of blood components on root surfaces instrumented by curettes, piezoelectric ultrasonic scaler and Er,Cr:YSGG laser. One hundred samples from 25 teeth were divided into 5 groups: 1) Curettes; 2) Piezoelectric ultrasonic scaler; 3) Curettes plus piezoelectric ultrasonic scaler; 4) Er,Cr:YSGG laser; 5) Curettes plus Er,Cr:YSGG laser. Ten samples from each group were used for analysis of root morphology and the other 10 were used for analysis of adhesion of blood components on root surface. The results were analyzed statistically by the Kruskall-Wallis and Mann-Whitney tests with a significance level of 5\%. The group treated with curettes showed smoother surfaces when compared to the groups were instrumented with piezoelectric ultrasonic scaler and the Er,Cr:YSGG laser. The surfaces instrumented with piezoelectric ultrasonic scaler and Er,Cr:YSGG laser, alone or in combination with hand scaling and root planing, did not differ significantly ( $\mathrm{p}>0.05)$ among themselves. No statistically significant differences $(p>0.05)$ among groups were found as to the adhesion of blood components on root surface. Ultrasonic instrumentation and Er,Cr:YSGG irradiation produced rougher root surfaces than the use of curettes, but there were no differences among treatments with respect to the adhesion of blood components.
\end{abstract}

Key Words: ultrasonic, dental scaling, regeneration, laser.

\section{INTRODUCTION}

Scaling and root planing (SRP) with manual instruments is the most established treatment of periodontal disease and has been shown to be effective in stabilizing its clinical parameters $(1,2)$. However, manual scaling has some limitations when used in difficult-toreach areas such as deep pockets and furcation lesions (3), namely the dependence on the operator's manual skills (4), reports of patient discomfort (5), excessive removal of dental tissue (3) and formation of smear layer, which impairs periodontal regeneration (6).

As a result, other tools have been developed to optimize the treatment of periodontitis, among which ultrasonic scaling and high-intensity lasers. Two types of ultrasonic devices are available in the market: piezoelectric and magnetostrictive sclaers, which differ according to instrument tip movement. The magnetostrictive ultrasound tip movement consists of a wave motion and piezoelectric ultrasonic tip has linear movements $(7,8)$. A study conducted with a piezoelectric ultrasonic device showed that it effectively removed dental calculus with less damage to the root surfaces compared to magnetostrictive ultrasonic and manual scaling (9). Additionally, clinical studies have shown that piezoelectric ultrasonic devices are effective in controlling periodontal disease when applied to nonsurgical periodontal therapy $(1,7)$ or during supportive

Correspondence: Guilherme José Pimentel Lopes de Oliveira, Faculdade de Odontologia, Departamento de Diagnóstico e Cirurgia, UNESP, Rua Humaitá, 1680, 14801-903 Araraquara, SP, Brasil. Tel: +55-16-3301-6369. Fax: +55-16-3301-6369. e-mail: guioliveiraodonto@hotmail.com 
periodontal therapy (5).

Among the high-intensity lasers, the Er,Cr:YSGG laser has demonstrated good dental calculus removal and smear layer removal without causing thermal damage to the root surfaces in in vitro studies $(10,11)$. The wavelength $(2.78 \mathrm{~mm})$ renders this laser a high degree of absorption by water, acting through the vaporization of water from the mineralized tissues, which reduces its thermal effects that may cause damage to the dental pulp, especially when not used under cooling (12). However, there are no studies making a direct comparison of the morphology and the biocompatibility of root surface irradiation with Er,Cr:YSGG and instrumented with piezoelectric ultrasonic devices.

This study used scanning electron microscopy (SEM) to evaluate the morphology and adhesion of blood components on root surfaces instrumented by curettes, piezoelectric ultrasonic scaler and Er,Cr:YSGG laser.

\section{MATERIAL AND METHODS}

This study used 25 single- or multi-rooted teeth from nonsmoking patients, extracted due to severe periodontal disease (attachment loss of more than one third of the root). These teeth were obtained from the Department of Diagnosis and Surgery, Araraquara Dental School, UNESP, after the patients read and signed the donation form.

\section{Sample Preparation}

After extraction, the teeth were washed in distilled water to remove blood and other deposits and kept at room temperature in a phosphate buffer solution $\mathrm{pH} 7.0$ (PBS), to keep the teeth hydrated up to the experiment.

The mesial and distal cervical third of the roots of these teeth were bordered by two parallel grooves performed using a carbide multiblade drill (577L; KG Sorensen, Barueri, SP, Brazil). The first groove was made at the cementoenamel junction, whereas the second was $5 \mathrm{~mm}$ distant on the root surface in the apical direction from the first groove. The areas bounded by the ridges were treated using curettes, piezoelectric ultrasonic scaler or laser irradiation, by a single operator. Then, a slow-rotating diamond-coated disk was used to section the teeth. The roots were crosscut in the first groove separating them from the crown, and were cut lengthwise in the buccolingual direction and then in the mesiodistal direction until the second grove was reached apically.
The samples were crosscut and separated into 2 samples of about $2 \mathrm{~mm} \times 2 \mathrm{~mm}$ in the mesial and distal surfaces, to examine adhesion of blood components and root surface morphology on the same root face, totalizing 4 specimens per tooth and hence 100 specimens, which were divided into 5 groups of 20 specimens each.

In group 1, the samples were treated by SRP, comprising 50 traction movements in the cervicalocclusal direction with a hand curettes (Gracey curette \#5-6; Hu-Friedy, Chicago, IL, USA). In group 2, the samples were instrumented with piezoelectric ultrasonic scaler (Piezon Master Surgery; Electro Medical Systems, Nyon, Genebra, Switzerland) with a RS3 tip, standard mode, $30 \mathrm{kHz}$ power, with a water rate of $30 \mathrm{~mL} / \mathrm{min}$ for $30 \mathrm{~s}$. In group 3, the samples were treated by SRP, comprising 50 traction movements in the cervicalocclusal direction with a hand curettes (Gracey curette \#5-6; Hu-Friedy) combined with piezoelectric ultrasonic instrumentation (Piezon Master Surgery; Electro Medical Systems) with a RS3 tip, standard mode, 30 $\mathrm{kHz}$ power, with a water rate of $30 \mathrm{~mL} / \mathrm{min}$ for $30 \mathrm{~s}$. In group 4, the samples were irradiated by Er,Cr:YSGG laser (Waterlase YSGG; BIOLASE Technology, San Clemente, CA, USA) with a $2.78 \mu \mathrm{m}$ wavelength and a sapphire tip (G4; size $600 \mu \mathrm{m}$; length of $4 \mathrm{~mm}$; transmission factor of $100 \%$ ), with $1.0 \mathrm{~W}$ power and $20 \mathrm{~Hz}$ frequency (140-150 $\mu$ s), irrigated with $10 \%$ air and $15 \%$ water for $30 \mathrm{~s}\left(29.99 \mathrm{~J} / \mathrm{cm}^{2} /\right.$ pulse $)$. The root was scanned in non-contact mode, at $45^{\circ}$ angulation to the surface. In group 5, the samples were treated by $\mathrm{SRP}$, comprising 50 traction movements in the cervicalocclusal direction with a manual curette (Gracey curette \#5-6, Hu-Friedy) and irradiated by Er,Cr:YSGG laser (Waterlase YSGG; BIOLASE Technology) with a 2.78 $\mu \mathrm{m}$ wavelength with a sapphire tip (G4; size $600 \mu \mathrm{m}$ sapphire; length of $4 \mathrm{~mm}$; transmission factor of $100 \%$ ), $1.0 \mathrm{~W}$ power and $20 \mathrm{~Hz}$ frequency $(140-150 \mu \mathrm{s})$, irrigated with $10 \%$ air and $15 \%$ water for $30 \mathrm{~s}\left(29.99 \mathrm{~J} / \mathrm{cm}^{2} /\right.$ pulse). The root was scanned in non-contact mode, at $45^{\circ}$ angulation to the surface.

All treatments were performed by a single trained operator. Next, 10 specimens from each group were subject to blood deposition and the remaining 10 of each group were morphologically evaluated. All specimens were examined by scanning electron microscopy (SEM).

Preparation for Analysis of Root Surface Morphology

For root surface morphology analysis, the samples 
were dehydrated in an ascending series of ethyl alcohols $(25,50,75,95$ and $100 \%)$, remaining $1 \mathrm{~h}$ in each solution. After this procedure, the samples were placed in acrylic plates, which received a hexamethyldisilazane (HMDS) application. First, each well received $0.8 \mu \mathrm{L}$ of HMDS $+0.8 \mu \mathrm{L}$ of absolute alcohol, measured by an automatic pipette (Boeco, Hamburg, Germany), where the specimens remained for $30 \mathrm{~min}$. The solution was then removed and the wells were filled with $1 \mathrm{~mL}$ of pure HMDS and the specimens remained there for $10 \mathrm{~min}$.

The specimens were bench dried for $20 \mathrm{~min}$. After drying, by a carbon dioxide critical point apparatus, the specimens were fixed on metal stubs and placed in a vacuum desiccator for $48 \mathrm{~h}$. After this period, the samples were sputter-coated with gold in a Bal-Tec SCD-050 device (Bal-Tec, GmbH, Witten, Germany) for $120 \mathrm{~s}$ and examined in a scanning electron microscope (Jeol JSM-330; Jeol, Tokyo, Japan) operated at $20 \mathrm{kV}$. SEM micrographs were taken with Fuji Neopan SS 120 film (Fuji Photo Film Co., Tokyo, Japan) under $\times 1000$ and $\times 2000$ magnifications. The SEM micrographs were analyzed by a previously trained blinded single operator, who described the morphology of the root surfaces with the modified index for the morphological analysis: $1=$ unchanged surface; $2=$ smooth surface; $3=$ rougher surface.

\section{Preparation for Adhesion of Blood Components}

For the analysis of adhesion of blood components on root surface, $10 \mathrm{~mL}$ of blood tissue were obtained from the peripheral vascularization of an adult nonsmoking patient, without systemic involvement, through puncture with a disposable syringe and needle. This produced was carried out at the School of Pharmaceutical Sciences of Araraquara, UNESP, after the patient had signed an informed consent form.

In all experimental groups, using a syringe and needle, blood was deposited on these specimens and maintained in a humidifier chamber for $20 \mathrm{~min}$. Next, they were washed 3 times, for $5 \mathrm{~min}$ each time, with a PBS solution $\mathrm{pH} 7.0$ in a shaker. Next, the specimens were identified and fixed in 1\% formaldehyde and phosphate buffer solution for $15 \mathrm{~min}$. After washing 3 times for $5 \mathrm{~min}$ each with a phosphate buffer solution, they were incubated for $10 \mathrm{~min}$ in $0.02 \mathrm{M}$ glycine and phosphate buffer solution and washed again. They were then fixed in $2.5 \%$ glutaraldehyde and phosphate buffer solution for $30 \mathrm{~min}$ and were washed again. The specimens were dehydrated in solutions of increasing ethyl alcohol concentrations of $25,50,75$ and $95 \%$, for $10 \mathrm{~min}$ in each concentration prior to washing three times for $10 \mathrm{~min}$ each in absolute ethyl alcohol. After drying, in a carbon dioxide critical point apparatus, the specimens were fixed on metal stubs and placed in a vacuum desiccator for $48 \mathrm{~h}$. After this period, the samples were sputter-coated with gold (Bal-Tec SCD050 device) for $120 \mathrm{~s}$ and examined in a scanning electron microscope (Jeol JSM-330; Jeol) operated at 20 kV. SEM micrographs were taken with Fuji Neopan SS 120 film under $\times 1000$ and $\times 2000$ magnifications. The SEM micrographs were analyzed by a previously trained blinded single operator, who described the adhesion of blood components using the Blood Component Adhesion Index (6): 0 absence of a fibrin network and blood cells; $1=$ scarce fibrin network and/or blood cells; $2=$ moderate fibrin network and moderate quantity of blood cells; $3=$ dense fibrin network and trapped blood cells.

\section{Statistical Analysis}

The software Bioestat 5.0 (Fundação Mamirauá, Belém, PA, Brazil) was used for statistical analysis. The statistical differences among the groups for analysis of root morphology and adhesion of blood components were evaluated by the Kruskal-Wallis nonparametric test. The Mann-Whitney nonparametric test was used to identify the statistically significant differences among the groups. The tests used in this study were applied with a significance level of $5 \%$.

\section{RESULTS}

\section{Analysis of Root Surface Morphology by SEM}

Figure 1A-E shows a panel of SEM micrographs illustrating the results of the root surface morphology analysis in the 5 groups.

Group 1 (SRP) - The SEM micrographs of the samples from this group showed smooth root surfaces in most cases ( 9 samples), only one sample showed an irregular surface (Fig. 1A). All samples showed the formation of smear layer and grooves without exposure of dentin tubules.

Group 2 (Piezoelectric ultrasonic scaler) - The root surface is rougher with the presence of grooves produced by the instrument, the presence of smear layer and occluded dentin tubules were the predominant 
features of root morphology produced by the treatment using a piezoelectric ultrasonic scaler $(80 \%)$, this pattern represents the score 3 (Fig. 1B). In $20 \%$ of the samples, a smooth root surface with the presence of smear layer and dentin tubules occluded was observed, and this pattern represents the score 2 .

Group 3 (SRP + Piezoelectric ultrasonic scaler) - The pattern in this group was similar to that found in group 2, where most of the samples showed the score 3 of root morphology, characterized by an irregular root surface, with the presence of grooves, smear layer and occluded dentin tubules (80\%) (Fig. 1C). The other
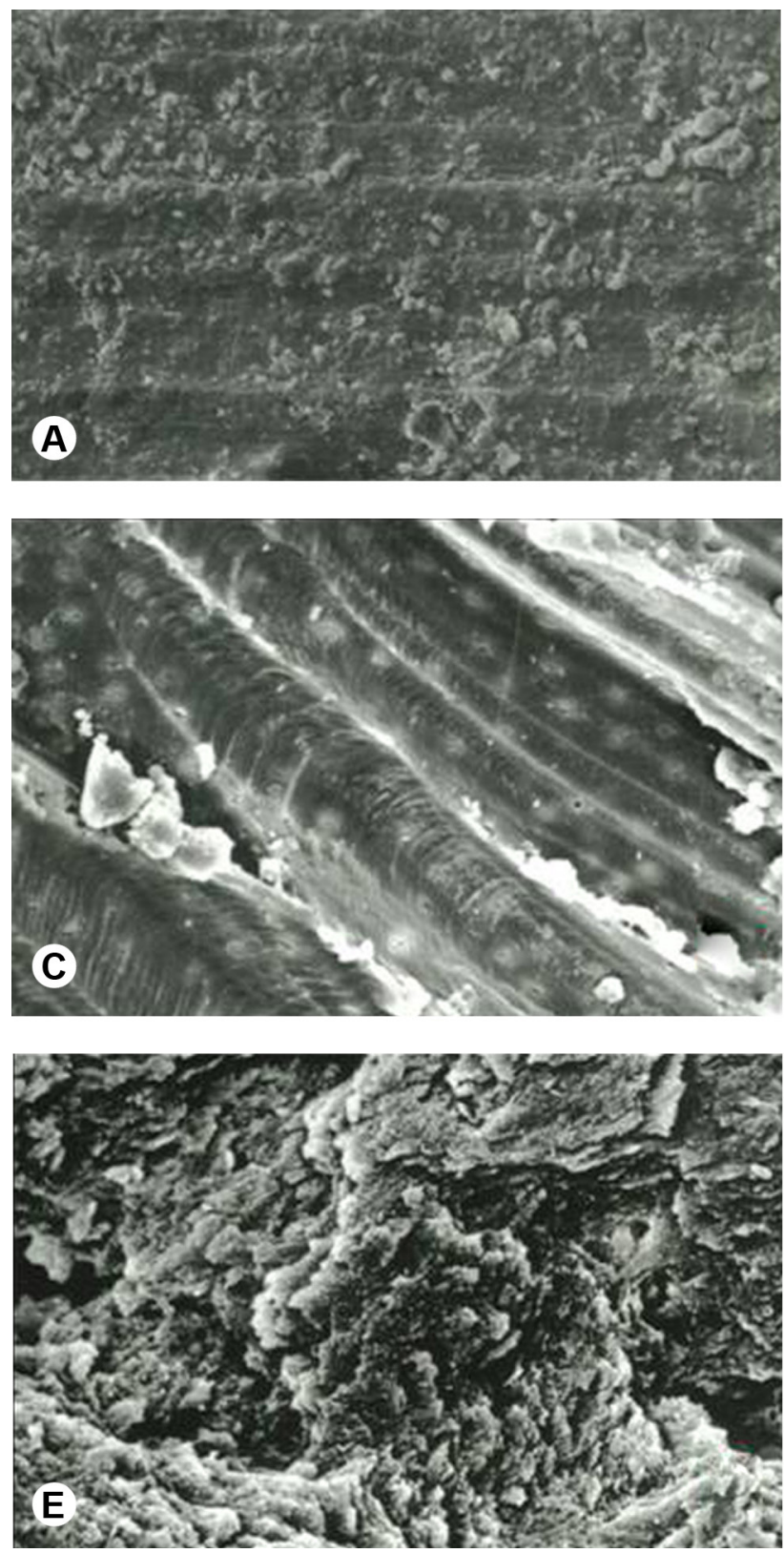

samples $(20 \%)$ presented a smooth surface, with the presence of smear layer and occluded dentin tubules, a pattern characterized by score 2 .

Group 4 (Er, Cr: YSGG) - The SEM micrographs of the samples in this group showed that all samples of the root surface were rough, with no smear layer, with open dentin tubules and the absence of thermal damage, and these characteristics represent the score 3 (Fig. 1D).

Group 5 (SRP + Er,Cr:YSGG laser) - The SEM micrographs of this group were similar to group 4, in which the root surfaces were significantly rough, with no smear layer, with open dentin tubules and with no
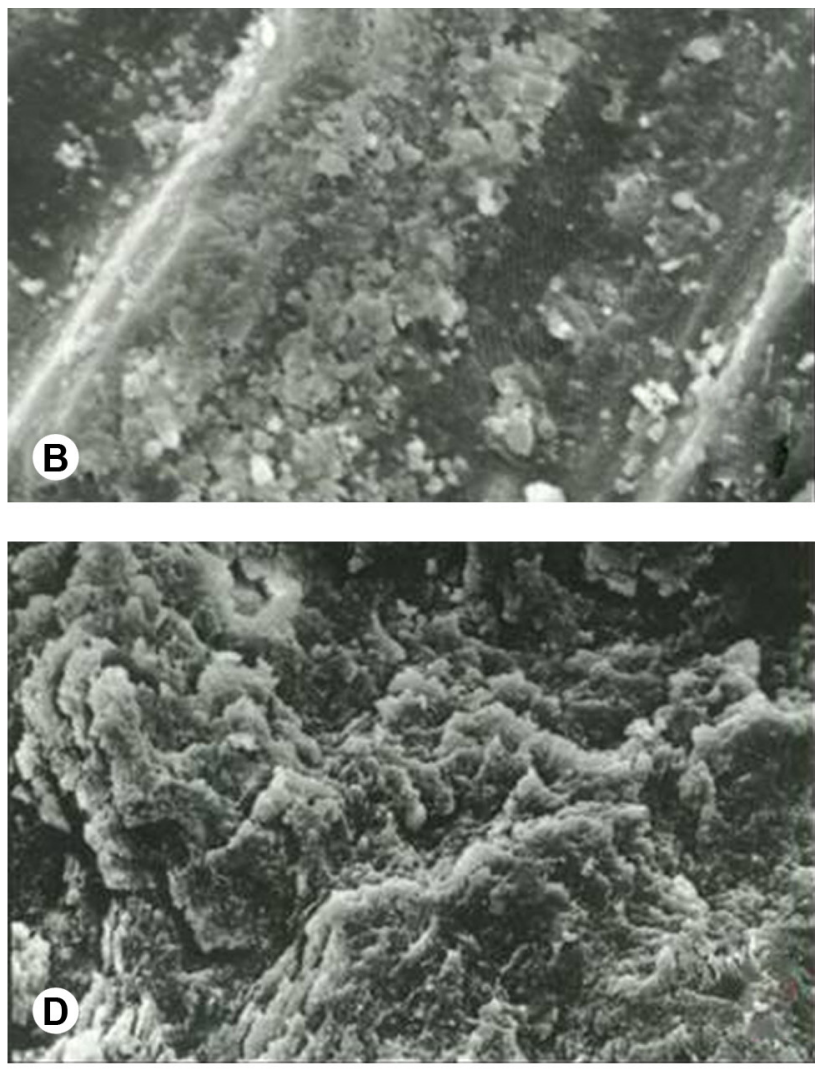

Figure 1. Panel of SEM micrographs illustrating the results of the root surface morphology analysis in the 5 groups. A= Group 1 (SRP). Smooth, flat and regular root surface with occluded dentin tubules and presence of smear layer (Score 2); B= Group 2 (Piezoelectric ultrasonic scaler). Irregular root surface, with grooves, occluded dentin tubules and presence of smear layer (Score 3); C= Group 3 (SRP + Piezoelectric ultrasonic scaler). Irregular root surface with the presence of grooves, occluded dentin tubules and presence of smear layer (Score 3); D= Group 4 (Er,Cr:YSGG laser). Irregular root surface with presence of microroughness, occluded dentin tubules and no smear layer (Score 3); E= Group 5 (SRP + Er,Cr:YSGG laser). Irregular root surface with microroughness, open dentin tubules and no smear layer (Score 3) (bar: $10 \mu \mathrm{m}$; original magnification: $\times 1000$ ). 
thermal damage (Fig. 1E).

The Kruskal-Wallis test showed statistically significant differences between the groups for the morphology of the root surfaces $(\mathrm{p}<0.0001)$. The Mann-Whitney test showed that the group scaled with hand instruments presented smoother surfaces when compared to the groups that were instrumented with the piezoelectric ultrasonic scaler (Group $1 \times$ Group 2, $p=$ 0.0082; Group $1 \times$ Group 3, $p=0.0082$ ) and Er,Cr:YSGG laser irradiation (Group $1 \times$ Group 4, $\mathrm{p}=0.0007$; Group $1 \times$ Group 5, $\mathrm{p}=0.0007)$. The root surfaces instrumented with the piezoelectric ultrasonic scaler and with the
Er,Cr:YSGG laser, alone or in combination with hand curettes were statistically similar to each other.

\section{Analysis of Adhesion of Blood Components by SEM}

Figure 2A-E a panel of SEM micrographs illustrating the results of the analysis of adhesion of blood components in the 5 groups.

Group 1 (SRP) - In this group, most root surfaces (6 samples) received score 3 of adhesion of blood components, which represents a dense fibrin network with a great interlacing and trapped blood cells (Fig.
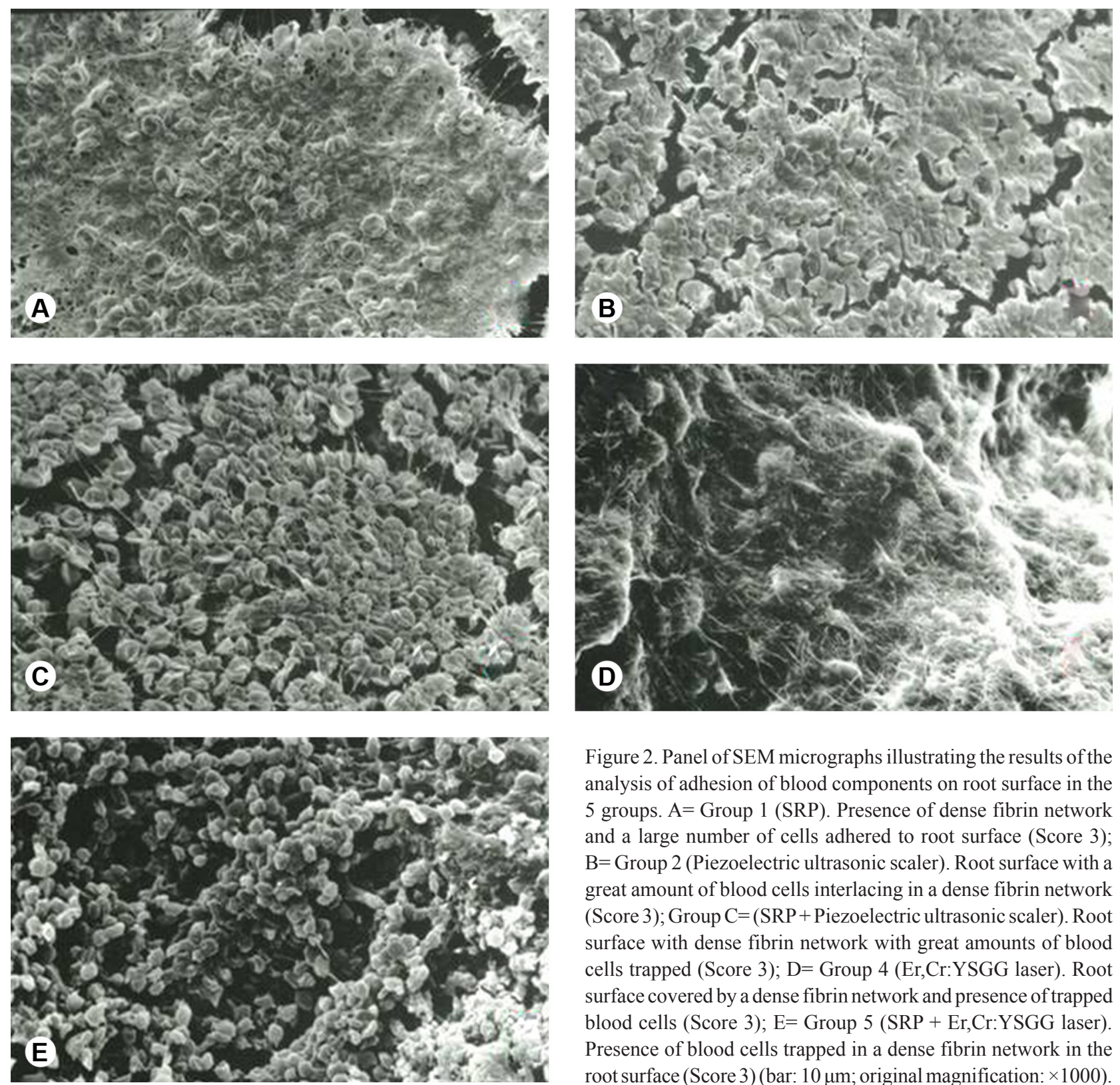

Figure 2. Panel of SEM micrographs illustrating the results of the analysis of adhesion of blood components on root surface in the 5 groups. A= Group 1 (SRP). Presence of dense fibrin network and a large number of cells adhered to root surface (Score 3); $\mathrm{B}=$ Group 2 (Piezoelectric ultrasonic scaler). Root surface with a great amount of blood cells interlacing in a dense fibrin network (Score 3); Group $\mathrm{C}=(\mathrm{SRP}+$ Piezoelectric ultrasonic scaler). Root surface with dense fibrin network with great amounts of blood cells trapped (Score 3); D= Group 4 (Er,Cr:YSGG laser). Root surface covered by a dense fibrin network and presence of trapped blood cells (Score 3); E= Group 5 (SRP + Er,Cr:YSGG laser) Presence of blood cells trapped in a dense fibrin network in the root surface (Score 3) (bar: $10 \mu \mathrm{m}$; original magnification: $\times 1000$ ). 
2A), which was followed by scores 1 and 2 (2 samples each) representing a scarce fibrin network and/or blood cells and a moderate number of blood cells and a thinner fibrin network with a small mesh, respectively. Samples with score 0 did not occur in this group.

Group 2 (Piezoelectric ultrasonic scaler) - Half of the samples in this group were scored 3 due to the presence of a large adhesion of blood cells trapped in a dense fibrin network (Fig. 2B). Score 0 was given to $40 \%$ of the samples, due to the lack of adherence of blood components. Ten percent of the samples were given score 1, which is characterized by scarce adhesion of blood cells trapped in a fine fibrin network.

Group 3 (SRP + Piezoelectric ultrasonic scaler) - Most samples in this group (40\%) received score 2, indicating a moderate adherence of blood cells trapped in a fine fibrin network (Fig. 2C). The other samples were distributed equally between scores 3 and 1 (30\% each), representing a large adhesion of blood cells trapped in a dense fibrin network and poor adhesion of blood cells trapped in a fine fibrin network, respectively.

Group 4 (Er,Cr:YSGG laser) - The samples of this group had higher frequency of score 3 (8 samples) showing a dense fibrin network with a great interlacing and trapped blood cells (Fig. 2D). The other samples received score 1 (1 sample), with the adhesion of scarce fibrin network and/or blood cells, and score 0 (1 sample) with no adhesion of fibrin network or blood cells.

Group 5 (SRP + Er,Cr:YSGG laser) - This group presented a higher frequency of score 3 for adhesion of blood components ( 5 samples), with a large adhesion of a dense fibrin network with great interlacing and trapped blood cells (Fig. 2E), followed by score 0 (3 samples), indicating no adhesion of blood components, and a score 1 ( 1 sample) and score 2 (1 sample), indicating an adhesion of a scarce fibrin network and/or blood cells and moderate amount of blood cells and fibrin network with little finer mesh occurred, respectively.

The Kruskal-Wallis test showed no statistically significant differences among the groups $(\mathrm{p}=0.39)$ as to the adhesion of blood components on root surfaces.

\section{DISCUSSION}

Analyzing the results of root morphology, it was observed that the samples that were scaled with hand curettes were smooth, with the presence of the smear layer and occluded dentin tubules. This pattern has been described in other studies $(6,13)$. The root surfaces instrumented with piezoelectric ultrasonic scaler and the Er,Cr:YSGG laser were rougher when compared to those scaled with manual instruments. However, the Er,Cr:YSGG laser promoted root surfaces with no smear layer and open dentin tubules, confirming the results already described in the literature $(10,11)$, while the piezoelectric ultrasonic device promoted root surfaces with smear layer and occluded dentin tubules, which is also consistent with other studies $(4,14)$.

The differences found between the morphological patterns found with instrumentation using piezoelectric ultrasonic scaler and Er,Cr:YSGG laser can be explained by their different tissue removal mechanisms. The piezoelectric ultrasonic device promotes tissue removal by linear vibratory movements of the tip and the cavitational active effect of irrigation water (15), and the roughness presented on root surfaces are due the scratches produced by the lower contact surface of the tip with the root surface, compared to manual instruments (3). The Er,Cr:YSGG laser, on the other hand, produces dental tissue ablation due to the high light absorption by water molecules present in the interprismatic tissue between the hydroxyapatite crystals $(10,16)$. These molecules evaporate quickly, causing tissue microexplosions and promoting the removal of hydroxyapatite crystals at temperatures below its melting point in a process called photomechanical ablation $(12,16)$. In addition to this, in our study, the Er,Cr:YSGG laser irradiated dentin tissue. This tissue is histologically divided into 3 parts: peritubular, intertubular and tubular, which have different water concentrations. Ablation occurs more rapidly in the intertubular tissue, with higher concentrations of water, compared to peritubular and tubular tissue, thereby allowing the formation of rough surfaces (12).

An important clinical aspect is the presence of a smooth, hard and resistant root surface after manual scaling $(17,18)$, but this pattern was not found in the present study when the piezoelectric ultrasonic scaler or Er,Cr:YSGG laser were used. Rough surfaces are related to higher biofilm accumulation, especially if these areas are located supragingivally (17). Because of this, the surfaces must be polished to avoid biofilm accumulation (18). Paradoxically, the subgingival rough areas can be beneficial to the healing of periodontal tissues, allowing the adhesion of a more stable fibrin network and the migration of fibroblasts and undifferentiated mesenchymal cells that will mediate the periodontal regeneration (6).

The results of adhesion of blood components 
showed no statistically significant differences between groups, demonstrating that the piezoelectric ultrasonic scaler and the Er,Cr:YSGG laser promoted a biocompatible root surface, but not superior to manual scaling. These results may be due to the lack of dental calculus and the efficiency of these instruments to remove endotoxins (19), despite the presence of smear layer and roughness promoted by these devices. Another factor that might have be beneficial to the adhesion of blood components was the absence of thermal damage observed in the groups. Thermal damages that could form toxic products from protein degradation, such as cyanamide, are related to the low biocompatibility of root surfaces irradiated with other types of lasers (6).

The results of adherence of blood components in the present study can explain the good clinical results obtained in previous studies using Er,Cr:YSGG laser irradiation (20) and piezoelectric ultrasonic instrumentation $(1,7)$, in which the clinical parameters of periodontal diseases were controlled. However, another study (14) demonstrated that the Er: YAG laser provided a greater adhesion of fibroblasts than ultrasonic instrumentation and manual scaling, unlike the present study in which the instrumentation techniques performed equally. However, one must take into account the different types of laser and ultrasonic devices and methodologies used in the studies to evaluate the biocompatibility of the root surfaces. It should be noted that the adherence of blood components to the root surfaces represents only the first stage of the healing process and thus further studies are needed to understand the in vitro effect of Er,Cr:YSGG laser irradiation and piezoelectric ultrasonic instrumentation on periodontal healing.

Considering the obtained results and the methodology used in this study, it may be concluded that piezoelectric ultrasonic instrumentation and laser irradiation with Er,Cr:YSGG laser, used alone or in combination with manual scaling, produced rougher root surfaces compared to scaling and root planing with curettes. However, despite the differences in root morphology, there were no differences in the adhesion of blood components among the treatments.

\section{RESUMO}

Esse estudo utilizou microscopia eletrônica de varredura (MEV) para avaliar a morfologia e a adesão de elementos sanguíneos em superfícies radiculares instrumentadas com curetas, ultrassom piezoelétrico e laser de Er,Cr:YSGG. Foram utilizadas no presente estudo 100 amostras provenientes de 25 dentes que foram divididas em 5 grupos: 1) Raspagem manual com curetas; 2) Raspagem com ultrassom; 3) Associação instrumento manual e ultrassom; 4)Irradiação do laser de Er,Cr:YSGG;5)Associação raspagem manual com irradiação com laser de Er,Cr:YSGG. Dez amostras de cada grupo foram utilizadas para análise da morfologia e as outras 10 foram utilizadas para a análise de adesão de elementos sanguíneos. As eletromicrografias foram analisadas através dos escores de adesão de elementos sanguíneos e pelo índice de morfologia radicular e os resultados foram analisados estatisticamente através dos testes de Kruskall-Wallis e de Mann-Whitney com nível de significância de 5\%. O grupo que foi tratado com instrumentos manuais apresentou superfície mais lisa em relação aos grupos que foram instrumentados com ultrassom e com o laser de Er,Cr:YSGG. As superfícies instrumentadas com ultrassom e com o laser de Er,Cr:YSGG de forma isolada ou associada a raspagem manual não apresentaram diferenças estatísticas entre si ( $p>0,05)$. Não houve diferenças estatísticas entre os grupos em relação a adesão de elementos sanguíneos $(p>0,05)$. A instrumentação ultrassônica e a irradiação com o laser de Er,Cr:YSGG produziram superfícies radiculares mais rugosas em relação a raspagem com curetas, porém não houve diferenças entre os tratamentos com relação à adesão de elementos sanguíneos.

\section{ACKNOWLEDGEMENTS}

The authors thank the granting authorities The São Paulo State Research Foundation (FAPESP) and The Brazilian Ministry of Health's Federal Agency for Support and Evaluation of Graduate Education (CAPES) for financial support of this study.

\section{REFERENCES}

1. Sculean A, Schwarz F, Berakdar M, Romanos GE, Arweiler NB, Becker J. Periodontal treatment with an Er:YAG laser compared to ultrasonic instrumentation: A pilot study. J Periodontol 2004;75:966-973.

2. Lopes BMV, Theodoro LH, Melo RF, Thompson GMA, Marcantonio RAC. Clinical and microbiologic follow-up evaluations after non-surgical periodontal treatment with Erbium:YAG laser and scaling and root planing. J Periodontol 2010;81:682-691.

3. Casarin RCV, Ribeiro FV, Sallum AW, Sallum EA, Nociti-Jr FH, Casati MZ. Root surface defect produced by hand instruments and ultrasonic scaler with different power settings: An in vitro study. Braz Dent J 2009;20:58-63.

4. Gómez C, Bisheimer M, Costela A, García-Moreno I, García A, García JA. Evaluation of the effects of Er:YAG and Nd:YAG lasers and ultrasonic instrumentation on root surfaces. Photomed Laser Surg 2009;27:43-48.

5. Braun A, Jepsen S, Deimling D, Ratka-Krüger P. Subjective intensity of pain during supportive periodontal treatment using a sonic scaler or an Er:YAG laser. J Clin Periodontol 2010;37:340345.

6. Theodoro LH, Sampaio JEC, Haypek P, Bachmann L, Zezell DM, Garcia VG. Effect of Er:YAG and diode lasers on the adhesion of blood components and on the morphology of irradiated root surfaces. J Periodont Res 2006;41:381-390.

7. Christgau M, Männer T, Beuer S, Hiller KA, Schmalz G. Periodontal healing after non-surgical therapy with a new 
ultrasonic device: a randomized controlled clinical trial. J Clin Periodotol 2007;34:137-147.

8. Santos FA, Pochapski MT, Leal PC, Gimenes-Sakima PP, Marcantonio Jr E. Comparative study on the effect of ultrasonic instruments on the root surface in vivo. Clin Oral Investig 2008;12:143-150.

9. Busslinger A, Lampe K, Beuchat M, Lehmann B. A comparative in vitro study of a magnetostrictive and a piezoelectric ultrasonic scaling instrument. J Clin Periodontol 2001;28:642-649.

10. Ting CC, Fukuda M, Watanabe T, Aoki T, Sanaoka A, Noguchi T. Effects of Er,Cr:YSGG laser irradiation on the root surface: morphologic analysis and efficiency of calculus removal. J Periodontol 2007;78:2156-2164.

11. Hakki SS, Berk G, Dundar N, Saglam M, Berk N. Effects of root planing procedures with hand instrument or erbium, chromium: yttrium-scandium-gallium-garnet laser irradiation on the root surfaces: a comparative scanning electron microscopy study. Lasers Med Sci 2010;25:345-353.

12. Ekworapoj P, Sidhu SK, McCabe JF. Effect of different power parameters of Er-Cr:YSGG on human dentine. Lasers Med Sci 2007;22:175-182.

13. Eberhard J, Ehlers H, Falk W, Açil Y, Albers H-K, Jepsen S. Efficacy of subgingival calculus removal with Er:YAG laser compared to mechanical debridement: an in situ study. J. Clin Periodontol 2003;30:511-518.

14. Crespi R, Romanos GE, Cassinelli C, Gherlone E. Effects of Er:YAG laser and ultrasonic treatment on fibroblast attachment to root surfaces: Na in vitro study. J Periodontol 2006;77:1217-1222.

15. Mendonça AC, Máximo MB, Rodrigues JA, Arrais CAG, Freitas PM, Duarte PM. Er:YAG laser, ultrasonic system and curette produce different profiles on dentine root surfaces: An in vitro study. Photomed Laser Surg 2008;26:91-97.

16. Harashima T, Kinoshita JI, Kimura Y, Brugnera Jr A, Zanin F, Pecora JD, et al.. Morphological comparative study on ablation of dental hard tissues at cavity preparation by Er:YAG and Er,Cr:YSGG lasers. Photomed Laser Surg 2005;23:52-55.

17. Folwaczny M, George G, Thiele L, Mehl A, Hickel R. Root surface roughness following Er:YAG laser irradiation at different radiation energies and working tip angulations. J Clin Periodontol 2002;29:598-603.

18. Kocher T, Rosin M, Langenbeck N, Bernhardt O. Subgingival polishing with a Teflon-coated sonic scaler insert in comparison to conventional instruments as assessed on extracted teeth. (II) Subgingival roughness. J Clin Periodontol 2001;28:723-729.

19. Braun A, Krause F, Frentzen M, Jepsen S. Removal of root substance with vector-system compared with conventional debridement in vitro. J Clin Periodontol 2005;32:153-157.

20. Kelbauskiene S, Maciulskiene V. A pilot study of Er,Cr;YSGG laser therapy used as an adjunct to scaling and root planing in patients with early and moderate Periodontitis. Stomatologija 2007;9:21-26. 